\title{
ダイヤモンドの熱的損 耗
}

田中義信** 井川直哉** 田中武司**

\section{1. 緒言}

ダイヤモンドは一般に空気中では $650^{\circ} \mathrm{C}$ 程度で然焼 乙やすくなり， $875^{\circ} \mathrm{C} て ゙ は$ 急激に燃焼するといわれてい る。また, 低圧空気中（たとえば 0.4 Torr）では, 同じ 程度の温度範囲でも表面に無定形炭素皮膜が生成される という報告もある1)。このようにダイヤモンドは熱的安 定性からいえば必ずしもすぐれては拧らず，これが研削 材としての適性をある場合には害するかもしれないし， また，焼結過程もふくむダイヤモンド工具の製造におい て問題となる.

ところで，ダイヤモンドの人工合成に注種々の金属触 媒が使用されるといわれるが，上にのべた熱損傷につい ても，たとえば，ダイヤモンドに接触している物質がな 几らかの促進作用を㧍こすことが類推される。したがっ て, ダイヤモンド工具の製造時における変質あるいは使 用時における摩耗などは, このような観点から十分検討 されなくてはならない。

筆者らは各種の粉末中で加熱されたダイヤモンドの損 傷について実験を行なってきたが，特に接触物質として の鉄の存在が重要であるという興味ある結果を得たので 報告する.

\section{2. 実験方法}

$10^{-4}$ Torr 程度の真空度を得, かつ最高 $1200^{\circ} \mathrm{C}$ の温 度で 2 時間程度一定の真空度を保持できる真空加熱炉を 用い, 石英製容器 $\left(25^{\phi} \times 10^{\phi} \times 14\right)$ に各種粉末とダイヤ

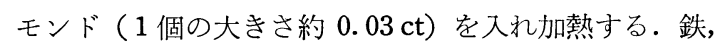
銅などの粉末では加熱により焼結が抢こるが，塩酸ある い注硝酸煮沸により粉末を溶かし, さらに酸化粉末を完 全に溶解するため修酸煮沸を行ない, ダイヤモンドを取 り出す. 加熱後のダイヤモンドの表面には黒鉛あるいは 炭素皮膜が着くことがあるが，これは濃縮クロム酸中で 煮沸して取り除く.

ダイヤモンドの損耗量は加熱前後のそれの重量を精密 化学天びえで測定して算出する.な抢，この場合の損耗

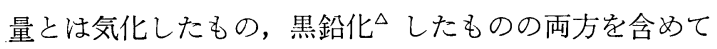
いる. また, 実験 結 果は試料数 5 個の算術平均值であ る.

${ }^{*}$ 原稿受付 昭和 45 年 4 月 6 日. 昭和 43 年度精機学会春季大 会学術講演会（昭和 43 年 4 月 5 日）にて発表.

**正 会 員 大阪大学工学部 (大阪府吹田市山田上)

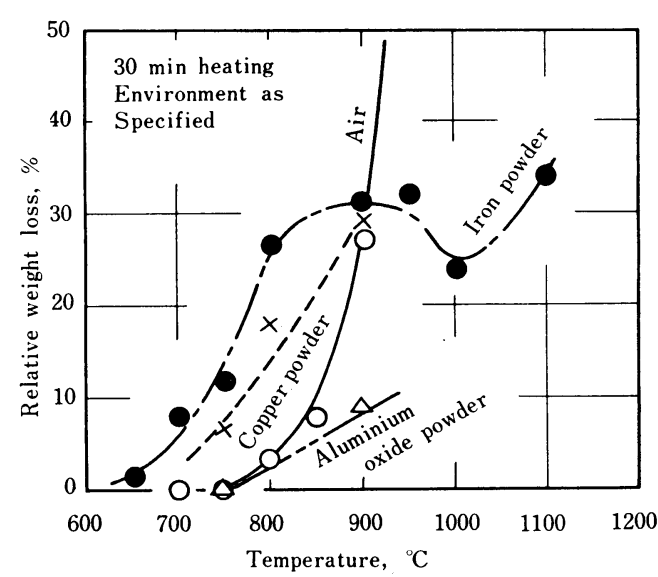

Fig. 1 Relative weight loss of Diamond as a function of Temperature

\section{3. 実験結果と考察}

大気圧中 $700^{\circ} \mathrm{C} \sim 1100^{\circ} \mathrm{C}$ の温度範囲で 30 分間加熱 し，ダイヤモンドの損耗を調べた結果を図 1 に示す.

一般にいわれるように, 空気中では約 $900^{\circ} \mathrm{C}$ になる と急激な損耗がみられる．鉄粉中でダイヤモンドを加熱 した場合, $500^{\circ} \mathrm{C}$ に打いては実験前後の重量变化もな く, 表面変化も認められない. $700^{\circ} \mathrm{C}$ で約 $7.7 \%$ の重 量減少がみられ, 表面泊色不透明となる。さらに, 温度 を $800^{\circ} \mathrm{C}, 900^{\circ} \mathrm{C}$ にあげると重量減少率法急激に増加す る.ところが, $1000^{\circ} \mathrm{C} て ゙ は$ 逆に重量減少率は減り, 1100

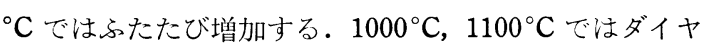
モンド表面には黑色皮膜が付着し，その厚さは $0.1 \mathrm{~mm}$ のオーダになる. $1000^{\circ} \mathrm{C}$ 以上で重量減少率が下がり, るいは飽和する傾向にあるのは，この近傍で黒鉛層の厚 さがかなり厚くなり，ダイヤモンドの黒鉛化に主要な作 用をなすとされている酸素がダイヤモンド表面に到達で きなくなるためと考元られる。この種の現像法酸素零囲 気中の実験でも示唆されている11 が，その機構は必ずし も明確ではない.

銅粉中での加熱では鉄粉中に比べ重量減少率は小とな っているが, $900^{\circ} \mathrm{C}$ で流ほぼ同一の值を示す.さらに, アルミナ粉中では他の粉末中に比べ減少率注小さくなっ ている.このことはアルミナ粉がこの温度範囲で化学的 に安定であるためと考えられ，金属粉末に比べてはるか

凶ここでは慣用的に用いる．これが無定形炭素であるか，黒鉛 であるかはとわない. 
にダイヤモンドの損耗に与皇影響は少ない。

図1の結果で注意す心゙きとと法，鉄，銅などの粉末で

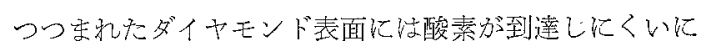
もか加わらず，約 $900^{\circ} \mathrm{C}$ 以下の加熱厄忹空気中よりも 損耗量が多く，接触物質の影響心゙歹られることである。

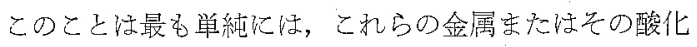

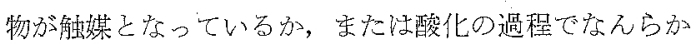
の作用を等すとい光る。

焉て，こ机らの穾験では，粉末中のダイヤモンドにあ る程度の酸素が到達することができ, 酸化化よりダイヤ モンドあるいは黒鉛の炭素が $\mathrm{CO}$ または $\mathrm{CO}_{2}$ となって

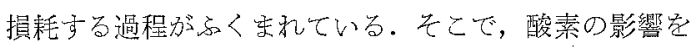
夕るために同様の実験堂堂度 $2 \times 10^{-3}$ Torx の槽内で 行なった。との場合の結果学1 に示す.

ぞの粉末中のダイヤモンドも損耗量は検出できない程 度の微量であり，損耗飞詨する酸素の影響が大であるこ とがわ加った。かし，乙れらのら台鉄粉中で加熱され たダイヤモンド表面は図 2 に示すよらな厚さ $0.1 \mathrm{~mm}$

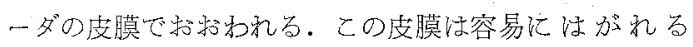

表 1 点空度 $2 \times 10^{-3}$ Torr 中, $900^{\circ} \mathrm{C}, 30$ 分間 加熹した時のダイヤモンドの变化*

\begin{tabular}{|c|c|}
\hline 末 & 变化の状態 \\
\hline 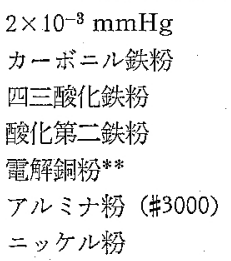 & $\begin{array}{l}\text { 表面変化なし } \\
\text { カーボンフィルム生成 } \\
\text { 表面変化なし } \\
\text { 表面変化なし } \\
\text { 表面変化なし } \\
\text { 表面変化なし } \\
\text { 表面不透明***. }\end{array}$ \\
\hline
\end{tabular}

“椇耗量注検出でき少い程度の微量 **他の粉末に比べて粗大 $* * * 1000^{\circ} \mathrm{C}$ で加熱

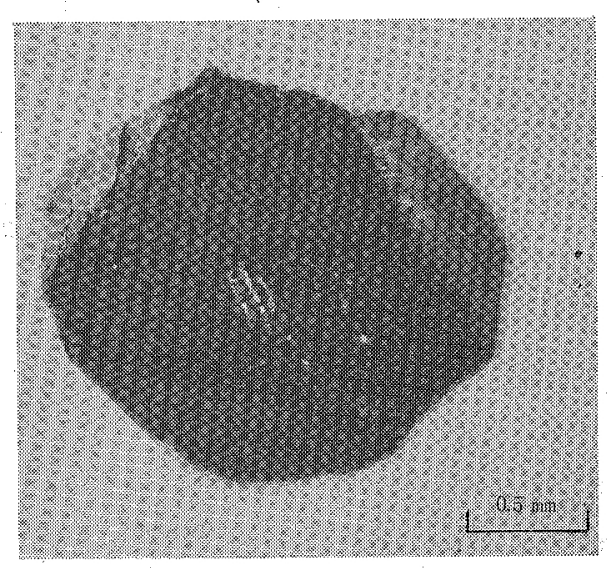

Fig. 2 Surface graphitization of Diamond embedded in iron powder heated at $900^{\circ} \mathrm{C}$ in Vacuum
が，とのるとにも黑化層怔残り，乙れは電子回折の結

果，黑鉛であることが推定さ秃た。

一方，表でわかるよらに，酸化鉄粉中ではまったく黑

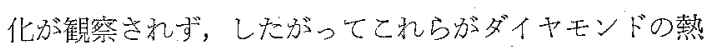

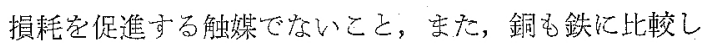

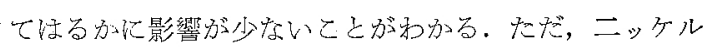
粉 $1000^{\circ} \mathrm{C}$ 加熱の時, わずか飞表面方不透明となり，㐫 る程度の影響が認められた。

さて，ダイヤモンドの酸素の存在のもとでの $1000^{\circ} \mathrm{C}$ 程度以下に和ける熱的損耗の機構についてはつぎよう

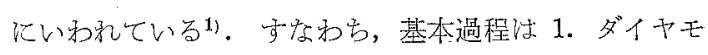
ソドの直接酸化 2. ダイヤモンドの黑鉿化 3. 黑鉛の酸 化の三つであるが，とのうち 1 忹無視できないが重要で なく，酸素の举動分重要な役割存なしている2と 3 によ り損耗の形態（たと党ば，表面皮膜）がきまるという。

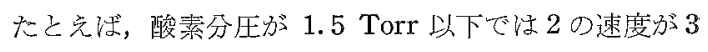
よりも大で，炭素敤膜汃できると報告されている。この ことは本実験の鉄粉中で加熱されるダイヤモントの状

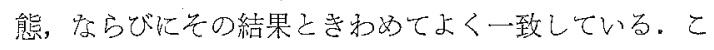
のことから類推すると，接蚛物質としての銠がんらか。 の意味で残留酸素学活性化し，それがダイヤモンド表面 飞作用して黒鉛化が促進されると考えられる。 その機構 は $\mathrm{Fe}$ が微量酸素のもとだ $\mathrm{FeO}$ となる過程2).での酸素 の挙動から説明できるかもしれない：また，銅粉中のダ イヤモンドに刘する結果も，銅の酸化過程が鉄と同様で あること老考えると矛盾がない。

な和，鉄の存在でダイけモンドの熱損耗が促進される 機棈について，ダイヤモンド名ら鉄中へカーボンが直接 桩散するといら見方もできるが，ダイヤモンドの表面に

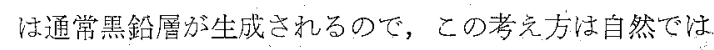
ない子思われる、純鉄ーダイヤモンドの拡散実験》でも。 その界面飞拡散量の数倍の黑鉛層务できる。

\section{4. 結言}

ダイヤモンド空各種粉末中で加熱した場会の損耗につ きつぎのことが明らかとなった。

1. 空気中 (大気压) 的 $900^{\circ} \mathrm{C}$ 以下では鉄粉あるい は銅粉につつまれたダイヤモンドの損耗量は露出 された場合よりも多い。

2. $2 \times 10^{-3}$ Torr 程度の糞空中 $900^{\circ} \mathrm{C}$ 加熱の場合の 損耗量炡大気王中にくらべて著しく少なくなる が，鉄粉中で加熱されたダィサモンドの表面に忹， 著し々黒鉛層吕生成される。

3. 以上の機構として，接触物質としての鉄の存在方 微量酸素の挙動学支配し，ダイヤモンド表面での 
黑鉛化を促がするのと類推される。

謝辞

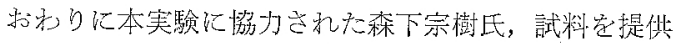

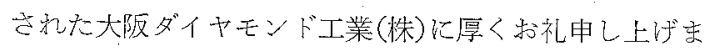

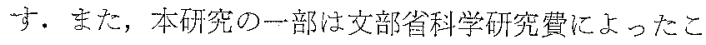
と繁記して謝意をあらます。

\section{参考文 献}

1) C. Phaal: Surface studies of diamond, Ind. Dia. Rev., 25, 300 (1965) 486.

2）たと元は，相江正慗：金属材料の加熱と酸化，工業技術全 甾, 誠文堂 (1965) 75 .

3) 田中義信, 井川直哉, 田中武司: 別報の予定.

\section{表紙説明一}

\section{厚膜 $\mathbb{I C}$ スクリーン印刷用広範囲スクリーン膜厚計}

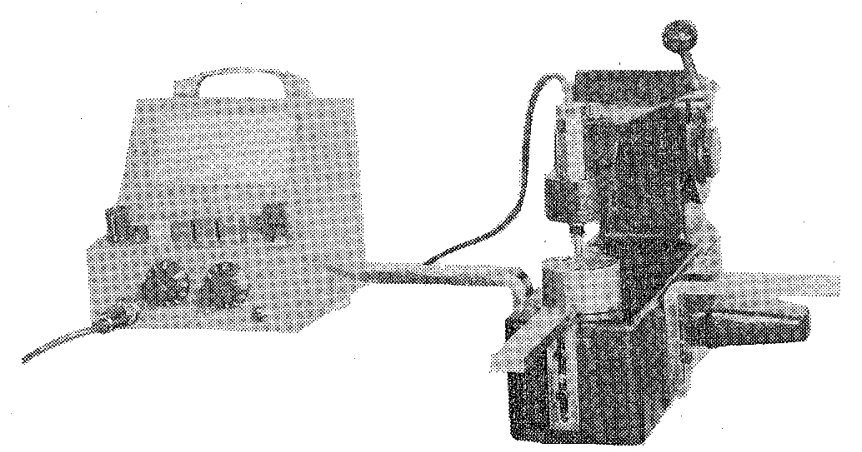

本器は厚膜 IC 墓用スタリーン製版の膜厚完測定する 専のです.

電子マイタロメータ方式で，膜厚寸法の微少変化琴電 気的に拡大して,メータで直読いたします. $\pm 1000 \mu の$ 広

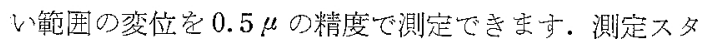
ンドのふところの厇さ（スピンドル先端から支柱までの 距離) は $160 \mathrm{~mm}$ ありますので, $5^{\prime \prime} \times 5^{\prime \prime}$ および $8^{\prime \prime} \times 10^{\prime \prime}$ の沉用稆其問題なく，乙か子簡単炕測定できます。

棈 成

1. 広範囲電子マイクロメータ

2. スピンドル検出器

3. 膜厚計用スタンド

仕 様

\begin{tabular}{|c|c|}
\hline 測 定 箦 团 & $0 \sim \pm 1000 \mu$ \\
\hline $\begin{array}{l}\text { 指示範囲 } \\
\text { ディケイドダイヤル } \\
\text { メータ指示範囲 } \\
\text { 最小目盛 }\end{array}$ & $\begin{array}{l} \pm 1000 \mu, \pm 50 \mu, \pm 250 \mu \\
\pm 10 \mu, \pm 50 \mu, \pm 250 \mu \\
0.5 \mu\end{array}$ \\
\hline $\begin{array}{l}\text { 指示誤差 } \\
\text { ディケイドダイヤル } \\
\text { 指示メータ }\end{array}$ & $\begin{array}{l}0 \sim \pm 200 \mu: \pm 0.5 \mu \\
\pm 200 \sim 1000 \mu: \pm(0.5 \mu+ \\
\text { ダイヤル指示值の士0.1\%) } \\
\pm(\text { 目量 } \times 1 / 2+\text { 指示値の1\%) }\end{array}$ \\
\hline 零点調整範团 & $\pm 50 \mu$ \\
\hline 出 力 & $-0.1 \sim-0.8 \mathrm{~V}$ 内部抵抗 $2 \mathrm{k} \Omega$ \\
\hline 測定加 & $30 \pm 5 \mathrm{~g}$ \\
\hline 源 & $100 \mathrm{~V}, 50 / 60 \mathrm{~Hz}$ \\
\hline スタンドフトコロ広さ & $160 \mathrm{~mm}$ \\
\hline
\end{tabular}

（本 社）東京都港区南麻布 4-12-20

(03) 446-1111

(支 店）大阪市大淀区中津本通 1-2

(06) $372-0521$

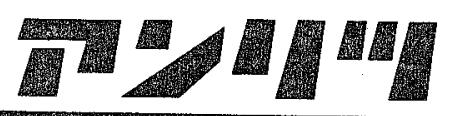

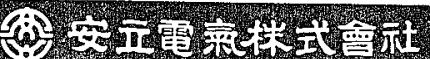

(名古屋)（052）582-7281

（札，幌）(0122）26-8391

(福 岡) (092) 76-5347

(厚 木) (0462) 22-3311 


\title{
一端に短い等分布質量をつけたピアノ絃の 振锶の INHARMONICITY*
}

\author{
柳沢 猛**：森岡幹夫*** 中村喜十郎**
}

\section{1。まえがき}

ピアノの楽音の偣第の inharmonicity 集積によって最近注㴗その本質が明らがさされ，

(1) 従来のピナノは inharmonicity がやや過大であって これが音筫と調律性老損じていること，

(2) ピアノ緮の改良は絃長と張才老大にすれば inharmonicity は小となるがすでに弾性限度いっぱいに設計 されているので，改良吉各余地は卧とえどなく，い米の ピアノ絃の構造ではどうにもならないとと，

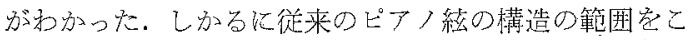

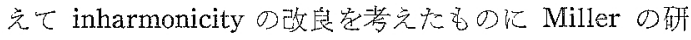

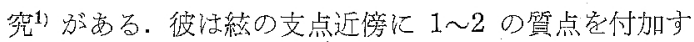

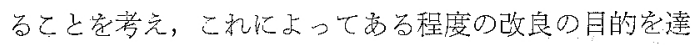
しらるとした，筆者はこれれついて検討したとこら，実

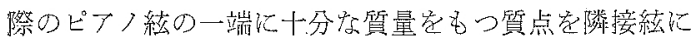

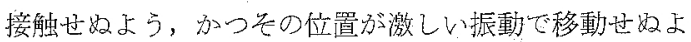
う，しか子䝷点の性質を保つ形で取り付けることは困難 であった。

ピアノ絃の振動の inharmonicity の生因や性質がいか

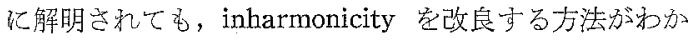
らないならば從来の研究は結局机上のものにすぎい。 このような観点加ら筆者はピアノ䊽の一端に等分布質量

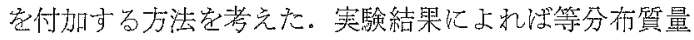
として銅線家巻き付け方方法は伝統的な構造のピアノ絃 に対して違和感㭬なく， inharmonicity の十分な改善驾 可能で离り，取付部の移期などの不都合性生じない。 (ただし巻線間のゅる夕は高次振動の減衰早わるか 注意它要する)

箠者はこの研究によってピアノ楽音の inharmonicity の問題注最終的に解決し得たものと思う。

\section{2. 実験}

実験に用いたピアノ絃の構造は図1のようである。図

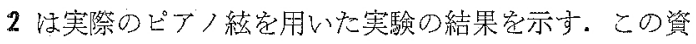
料によるとピアノ絃の inharmonicity は振動の各次数に

*原稿受付 昭和45年 4 月 22 日，昭和44年度精機学会春季大 会学術請演会（昭和44年 4 月 5 日）にて発䘚.

**正 会 員 静岡大学工業短期大学部 (浜松市城北 3-5-1)

****正 会'員 静网大学教育学部（静岡市大谷 836）

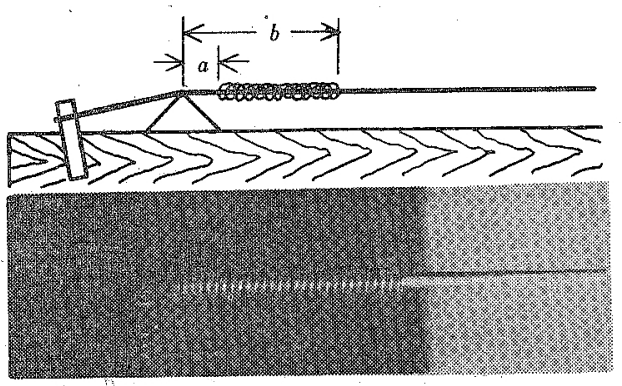

(a) 中高音部

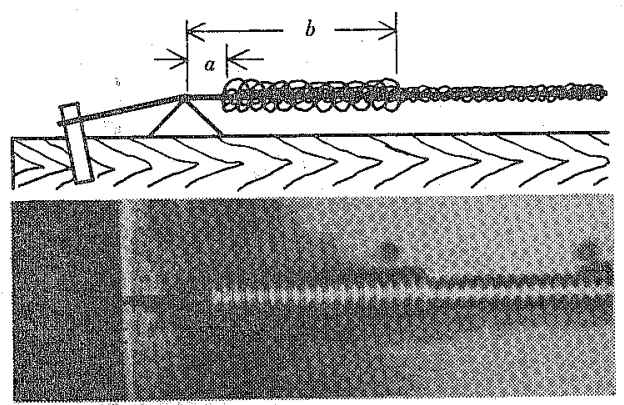

(b) 低音部

图 1 分布質量の付方

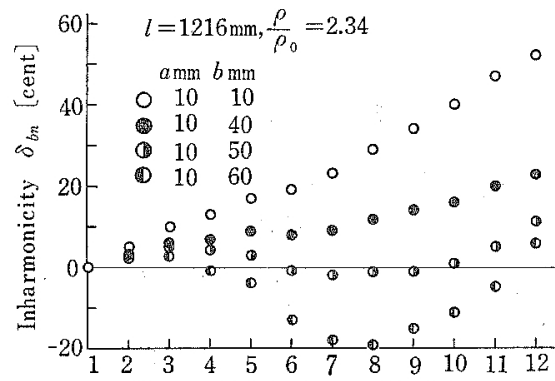

(1) $\mathrm{A}_{1}(27.5 \mathrm{~Hz})$ 振動次数 $n$

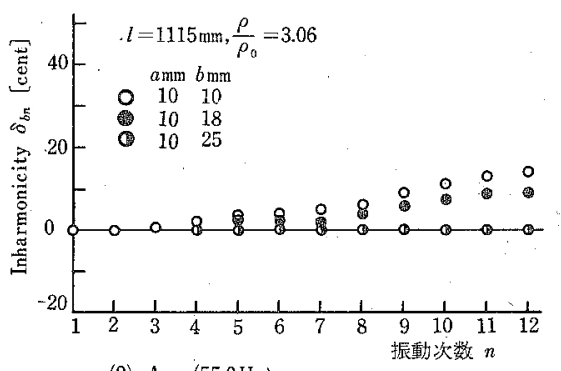

(2) $\mathrm{A}_{13}(55.0 \mathrm{~Hz})$

図 2 付加暨量による INHARMONICITY の変化 

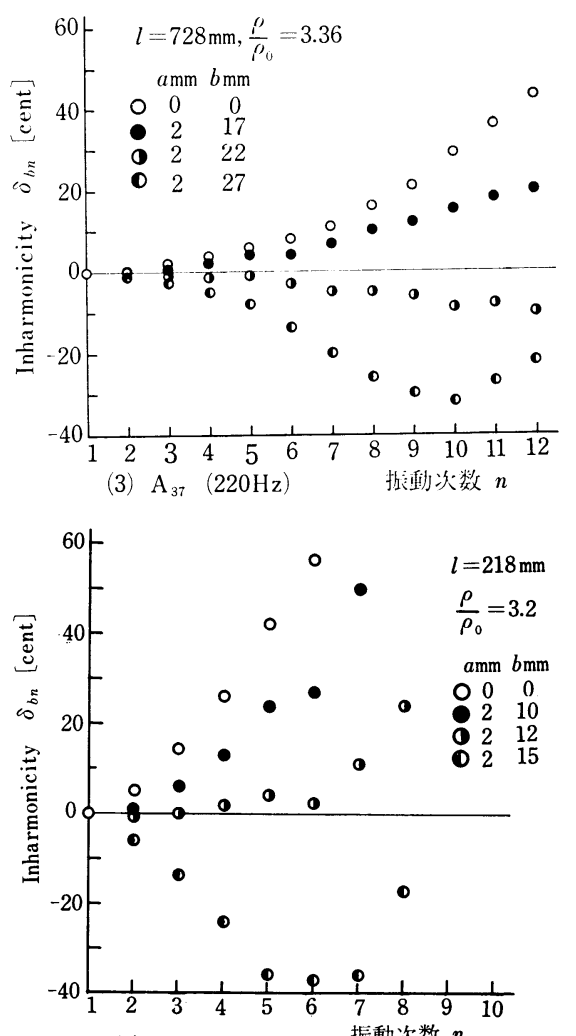

(5) $\mathrm{A}_{61}(880 \mathrm{~Hz})$
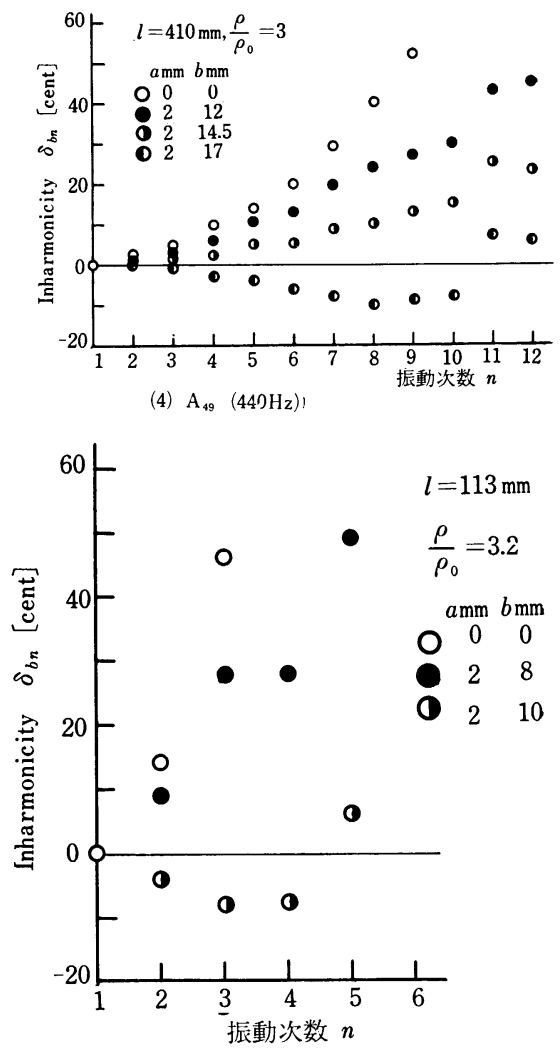

(6) $\mathrm{A}_{73}(1760 \mathrm{~Hz})$

図 2 付加質量による INHARMONICITY の変化

わたり，ほぼ一様に減少することが認められる。

\section{3. 解 析}

ピアノ絃は図 3 のような振動系と考えて解析する。こ こで $l$ 注絃長, $a$ は裸部長さ, $b$ は付加質量部長さ, $E$ は ヤング率， $I$ は断面二次モ一メント， $\rho_{0}$ は線密度， $\rho$ は 付加質量部の線密度, $T$ 汇張力, $B=\pi^{2} E I / T l^{2}, n$ 注振 動の次数, $f_{o n}$ は付加質量のない絃の振動数, $f_{b n}$ は付加 質量を有する絃の振動数である. 筆者の論交 2)「ピアノ の銅巻絃の振動, 一一両端の裸部長さと inharmonicity 一」に䋆て $a$ を $b$ とかきかえ，lを $2 l$ とかきかえる

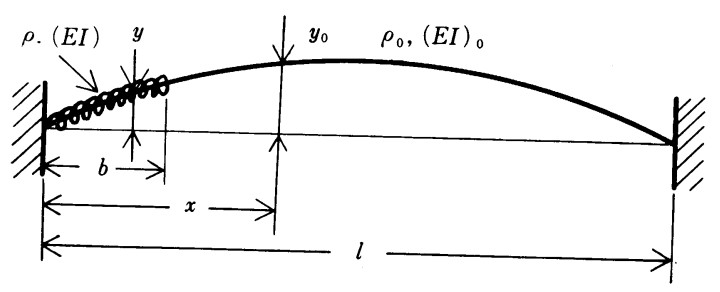

図３＼cjkstart分布荷重を有する振動系
とその偶数次の振動がこれと一致する.図 3 の系の $b$ の 大小による振動数への影響係数を $\varepsilon_{b n}$ とすると

$$
f_{b n} \fallingdotseq f_{o n}\left(1+\varepsilon_{b n}\right)
$$

であるが，前論文のごとき解析を行なうと

$$
\begin{gathered}
\varepsilon_{b n} \doteqdot \frac{1}{3} n^{2} \pi^{2}\left(1-\frac{\rho}{\rho_{0}}\right)\left(\frac{b}{l}\right)^{3} \\
\text { ただし } n \pi b / l \ll 1
\end{gathered}
$$

となり図 3 の系の inharmonicity $\delta_{b n}$ は

$$
\delta_{b n} \fallingdotseq \delta_{o n}+\Delta_{b n}
$$

ただし $\delta_{o n} \fallingdotseq 866\left(n^{2}-1\right) B \quad$ [cent]

$$
\Delta_{b n} \fallingdotseq 577 \pi^{2}\left(n^{2}-1\right)\left(1-\frac{\rho}{\rho_{0}}\right)\left(\frac{b}{l}\right)^{3} \text { [cent] }
$$

ここに $\rho / \rho_{0}>1$ であるから $\varepsilon_{b n}$ や $\Delta_{b n}$ は負值をとり, したがって図 3 の系の inharmonicity $\delta_{b n}$ を零とする条 件は近似的に次式となる。

$$
\left(\frac{\rho}{\rho_{0}}-1\right)\left(\frac{b}{l}\right)^{3} \fallingdotseq-\frac{3 B}{2 \pi^{2}}
$$

\section{4. 実験值と解析值の比較}

試料ピアノ絃の実験值 $\delta_{b n}$ から 


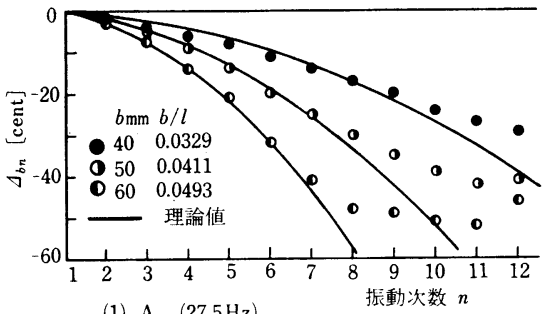

(1) $\mathrm{A}_{1}(27.5 \mathrm{~Hz})$
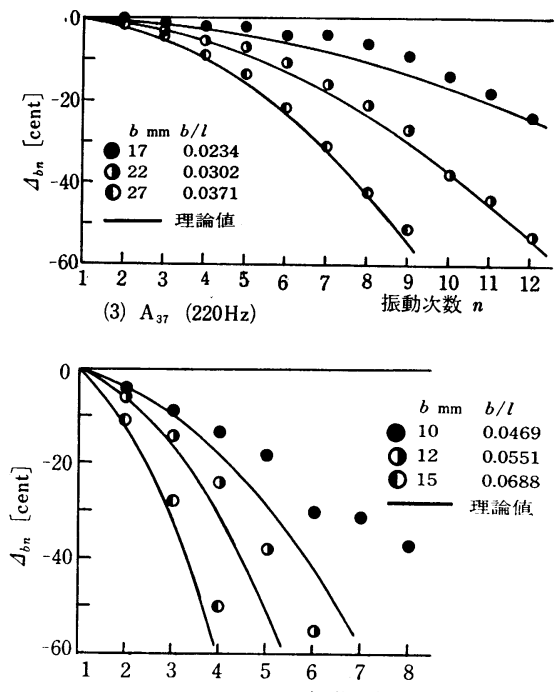

(5) $\mathrm{A}_{61}(880 \mathrm{~Hz})$

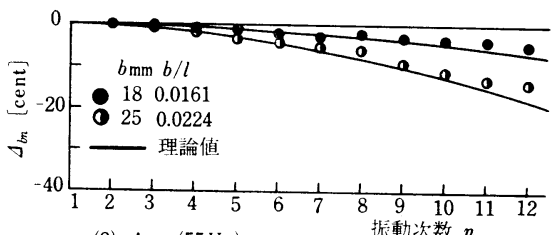

(2) $\mathrm{A}_{13}(55 \mathrm{~Hz})$

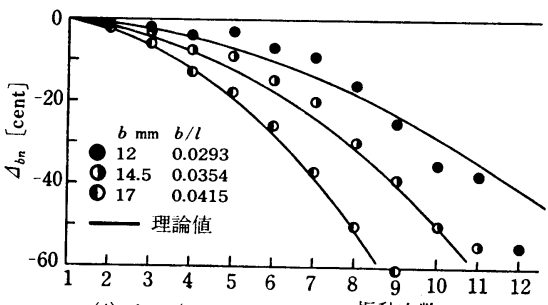

(4) $\mathrm{A}_{49}(440 \mathrm{~Hz})$

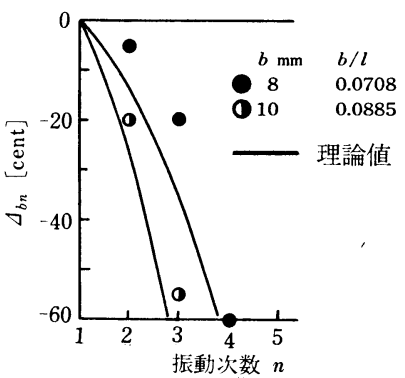

(6) $\mathrm{A}_{73}(1760 \mathrm{~Hz})$

図 $4 J_{b n}$ の理論倠之於験值の比較

$$
\begin{array}{ll}
J_{b n} \fallingdotseq \delta_{b n}-\delta_{10 n} & \text { (低音部銅巻絃) } \\
J_{b n} \doteqdot \delta_{b n}-\delta_{0 n} & \text { (中高音部裸絃) }
\end{array}
$$

を求め，これと解析值之学比較すると図40ようにな る. 低音部の $\delta_{10 n}$ というのは裸部長さ $a=10 \mathrm{~mm} の も$ のでありその意味泩前論交2)にのベてある.

（1）最低音部（およそ第 5 鍵丈で）たとえば $\mathrm{A}_{1}$ の場合 図 2 (1)沉ると $b$ 最適値は 40〜 $50 \mathrm{~mm}$ であるが，こ れを図 4 (1)に扮いて解析近似值と比較すると $b$ の值のこ の付近では第 8 倍音まではよい一致を示している。特に 最低音部は $B$ 值が大きいのだ inharmonicity 改善のため に法分布質量部長さ $b$ 艺大きくする必要がある。 $b$ を大 にすると次数 $n$ が大きいところでは(2)式の条件からはず れ解析值と実験值のずれが大となる．しかし図 $2(1)$ で見 られるようにもとの inharmonicity と比較すれば著しく 改善され，実用上はこの程度でよい。

（2）低中音部 ここは inharmonicity は小であり $\mathrm{A}_{13}$ ， $\mathrm{A}_{37}$ にみられるように実験值と解析值とはよく一致する。 (3) 高音部 たとえば図 2 (5)の $\mathrm{A}_{61}$ にみられるように振 動の次数 $n$ に対して inharmonicity の増加が大きい。
た高音部ではその基本振動数がすでに相当高いので，そ の高次振動数はさらに高く， $\mathrm{A}_{61}$ のたとえ第 6 次振動 数は約 $5300 \mathrm{~Hz}$ であるが，このあたり以上の高調波は 周波数成分が弱く, 打絃直後瞬間的に減衰するためその inharmonicity の存在は気にならない。したがってこの 絃で第 6 次以上を考慮しても意味がない。 また $\mathrm{A}_{73}$ で 注同様の理由で第 3 次以上の inharmonicity 法考慮しな くてもよい.さらに最高音部の1オクターブについては もはや inharmonicity は考慮の必要がないように思われ 万.

実際に実験の結果からみると全音域にわたり(2)式成立 の条件注

$$
\frac{n \pi b}{l}<0.5
$$

の筙囲で解析值とよく一致している.

\section{5. 付加卷線を実施する場合}

市販のピアノ絃はアップライトピアノでは付加巻線の

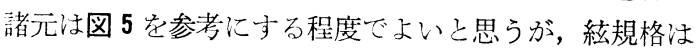




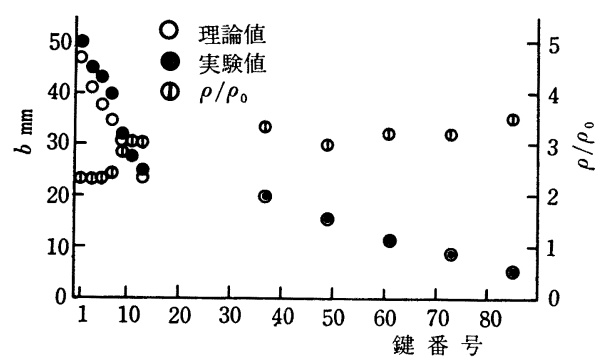

図 5 線密度比と付加質量部長さ

メーカによってわずかに差があるためつぎのようにして 決定すれ壮よい。 まず最適の付加巻線の直径を定めるこ れは振動中に隣接絃に触れない程度になるべく大きくす る.つぎに inharmonicity が適当となるように付加巻線 の長さを調節する.

ここに注意すべきは付加巻線の巻き付けに祭して, 巻 線間にゆるみが生ずると高次高調波の減衰が早くなり， 音質をとこなうことである。

\section{5. 結言}

従来のピアノ絃に対して眓1のような一様分布質量を 駒側端に付加すると図 2 のように inharmonicity の小さ い絃が得られる．振動系を図 3 とすると付加質量の影響 は理論的に(2)式で表わされ，この計算值と実験值の比較 は図4のようである。また inharmonicity 零の条件法(6) 式である・ただし実施にあたり，質量を付加することに よって巻き付け銅線がゆるむと高次の高調波成分が急激 に減衰するから十分注意しなければならない。

\section{文献}

1) Franklin Miller: A Proposed Loading of Piana Strings for Improved Tone, JASA, 21, 4 (1949) 318.

2) 柳沢 猛, 森岡幹夫, 中村喜十郎: ピアノの銅巻紘の层 動, 両端の裸部長さと inharmonicity, 精密機械, 34, 6 (1968) 382. 